\title{
A SURVEY ON EXCHANGE RATES DETERMINATION IN THE TEACHINGS OF THE AUSTRIAN SCHOOL*
}

\author{
MASSIMILIANO NERI**
}

Resumen: El presente ensayo representa una recopilación de las contribuciones de prominentes economistas austriacos sobre la determinación del tipo de cambio (Mises, Hayek, Haberler). En la primera parte se repasan los fundamentos teoréticos que permiten una comprensión exhaustiva de las fuerzas microeconómicas que determinan el tipo de cambio. A continuación se examina la teoría de la paridad de poder adquisitivo, tanto desde un punto de vista austriaco como neoclásico. Finalmente se inspeccionan los movimientos internacionales de dinero y las asociaciones de los mismos con las dinámicas de la balanza de pagos y del tipo de cambio. Se deja abierta la puerta para futuras investigaciones sobre la idea de incorporar la noción de la paridad de tipo de interés, entendida como «ley de tendencia», dentro de la teoría austriaca.

Palabras clave: Tipo de cambio, análisis austriaco, paridad del poder adquisitivo, balanza de pagos, movimientos internacionales de capital.

* I am grateful to Prof. Jesús Huerta de Soto, Prof. Guido Hülsmann and Prof. Roger Garrison for their suggestions on the essential literature on this subject. The bibliography was also inspired by Prof. Joseph Salerno's article, «International Monetary Theory» (1994). I am also indebted to Prof. Jesús Huerta de Soto, Prof. Miguel Ángel Alonso, Philipp Bagus, Giancarlo Ianulardo and William Longhi for the significant feedback they provided on the first draft of this survey. All errors are obviously mine.

** Universidad Rey Juan Carlos, Madrid. 
Abstract: This survey represents a recollection of the contributions of prominent Austrian economists on the subject of the exchange rate determination (Mises, Hayek and Haberler). We review the theoretical fundaments that allow for a comprehensive understanding of the microeconomic forces that determine exchange rates. Then we examine the Purchasing Power Parity Theory, both from a neoclassical and Austrian viewpoint. Finally we inspect the international movements of money and the associations of these with the dynamics of the balance of payments and exchange rate. We leave open the door for future investigations over the idea of incorporating the notion of the Interest rates Parity, intended as a "tendency law», in the Austrian theory.

Key words: Exchange rate, Austrian theory, purchasing power parity, balance of payments, international capital movements.

Clasificación JEL: F31.

\section{INTRODUCTION}

The problems that arise from the theoretical analysis of the exchange rate determination pertain to the field of the Theory of International Trade. This field of knowledge can be partitioned into the 'pure' theory of international trade and the 'monetary' theory of international trade, the former being concerned with the 'real' factors that promote an international exchange while the latter with the phenomena that take place when the monetary factor is introduced.

In the ground of International Trade Theory, the Austrian School produced its main contributions in an unsystematic way; an organic treatment does not exist ${ }^{1}$. For this reason, it makes sense to compile a collection of the isolated contributions of the

${ }^{1}$ The highlights in this field are the works of Mises, Hayek, and Haberler, whose most important contributions are mentioned in the bibliography. 
Austrians on the subject of exchange rate determination, which is precisely the scope of the present survey.

The doctrines that seek to preserve purchasing power stability, price stability and exchange rate stability by means that are not in line with sound money policies, have been exhaustively examined and criticized by the Austrians. Although they represent a very interesting subject, they do not fall within the scope of this work, and will not be mentioned unless they prove to be useful for our investigation.

\section{PURCHASING POWER OF MONEY AND MONETARY EQUILIBRIUM}

\section{Micro foundation of international trade analysis}

The Austrian analysis has a microeconomic foundation. Applying the principle of methodological individualism ${ }^{2}$, the Austrians derive the laws of economics focusing on the economic behavior of individuals or firms and not on the movements of aggregates of individuals, or collectives. It is not an aim of this work to review the sociological and epistemological reasons in favor of this methodological approach ${ }^{3}$. Suffice it to say that all the

\footnotetext{
${ }^{2}$ Haberler (1950), p. 7.

3 To resume very briefly, methodological individualism had been ascribed as a basic principle by the founder of the school, Carl Menger. Giving a systematic epistemological foundation to the school, it was probably Ludwig von Mises who best described the principle and the dangerous errors generated by the scientist that neglects it. From the epistemological point of view, it is easy to demonstrate that no type of collective (a family, an association, a chamber of commerce, a political party, the Government, etc.) exists without the presence of the individual, and that its manifestations are the outcome of the complex interaction of individual actions (Mises, 1963, «The Principle of Methodological Individualism», p. 41). From the economical point of view, Mises articulated the traps of the macroeconomics approach, which focuses upon an arbitrarily selected segment of the economy (for example, upon one nation). This macroeconomic aggregate is constituted by groups of individuals acting in concert, but macroeconomics today proceeds as if all these individuals'
} 
members of the school adhere to it, with no exceptions, and this leads to very interesting implications in the field of macroeconomics and monetary theory. For example, in the present work, this methodology manifests itself in Mises' analysis of the purchasing power of money, in his definition of the demand for money, and in Hayek's investigation of the workings of an international monetary system in the case of an homogeneous international money.

\section{The objective exchange value of money}

The concept of the objective exchange value ${ }^{4}$, popularly called 'purchasing power', enables an understanding of the essential difference between money and other economic goods. The subjective valuation of the individual is the basis for the determination of the economic value of money, as with any other economic good. Every economic good has both a use-value and an exchange-value. Since money is useful only as a medium of exchange, its subjective use-value and subjective exchangevalue coincide. Moreover, while the utility of an economic good is determined both by its subjective use-value and the value scale of the individual ${ }^{5}$, the utility of money (that is, its subjective

actions were in fact the outcome of the joint operation of one macroeconomic magnitude upon another (Mises, 2002b, «The Approach to Macroeconomics»). For a justification of how Austrian Macroeconomics can be conceived without stumbling into these ingenuities, the most advanced contribution comes from Professor Roger Garrison's Time \& Money, 2001 (The Macroeconomics of Capital Structure, p. 3).

4 Mises introduced this concept in one of the most fascinating and important chapters ever written for Austrian Economics (1953, Ch. I, Part II, p. 97). This chapter represents the foundation of his theory of the value of money.

5 Mises calls the former 'external factors' and the latter 'internal factors'. Ibid. Here we see how Mises had not yet developed a comprehensive subjective stance in his economic analysis, since at a later stage (in «Human Action») we find that even the external factors are determined by subjective valuation only. More specifically, an economic good is a means for the economic agent as long as he subjectively thinks so; in other words, its use-value is not determined by objective factors but by the subjective belief that a good is useful in order to attain the selected goal. 
value as a means of exchange) depends only on its objective exchange-value.

The 'objective exchange' value of money is defined as the possibility to obtain a certain quantity of other economic goods in exchange for the former ${ }^{6}$; the price of money is this same quantity (for example, we could speak of the commodity-price of money). This is not the place to examine further the implications of this concept (such as the apparent circular reasoning implied in the previous definition, or the formation of the purchasing power of money), since they have been addressed exhaustively by Mises ${ }^{7}$.

\section{Monetary equilibrium}

The monetary equilibrium towards which the market continues to drive can be described as one in which the purchasing power of money is absolutely equal everywhere ${ }^{8}$. Mises examined geographical differences in the purchasing power of money ${ }^{9}$ by pointing out that the same physical good does not represent the same economic good in different locations. In fact, two identical goods do not belong to the same class if they are not ready for consumption in the same place, since transport and distribution costs affect their final price ${ }^{10}$.

${ }^{6}$ We can also affirm that the use-value of money is the anticipated use-value of the goods we intend to purchase with it.

${ }^{7}$ See the entire chapter II, part II (The Determinants of the Objective ExchangeValue, or Purchasing Power of Money) in Mises (1953).

8 Salerno (1984), p. 251.

9 Mises (1953), Ch. III, Part II, pp. 170-179.

${ }_{10}$ Mises lost for a moment his subjectivist stance when he claimed that: «The money-price of any commodity in every place [...] must be the same as the price at any other place, augmented or diminished by money-cost of transport». Clearly, subjective valuations change depending on the location of the purchases. This is true if we consider, for example, a can of Coca Cola consumed in a five-star hotel versus its purchase in a supermarket; the same applies to the price of a Big Mac in two different countries. Hence, the transport cost is only one of the factors that justify 
This argument confirms why it is inconceivable to state that interspatial discrepancies in the purchasing power of money are demonstrated by the observation of price differences for the same goods. However, we can go a step further. The transport cost of money is virtually zero ${ }^{11}$, therefore if we assume as nil the cost of moving money, and if we remember that the individual's value scale does not intervene in the determination of the subjective exchange-value of money, we ascertain that the purchasing power of money should be the same the world over. In the words of Mises: «The purchasing power of money shows a tendency to come to the same level throughout the world, [...] the alleged differences in it are almost entirely explicable by differences in the quality of the commodities offered and demanded, so that there is only a small and almost negligible remainder left over, that is due to differences in the quality of the offered and demanded money» ${ }^{12}$. Salerno adds that this renders the location of money a matter of indifference to economic agents; therefore money represents a perfectly fungible commodity, subject to the operation of the Law of One Price.

\footnotetext{
the different quotation of a given product in different geographical areas. However, we cannot forget that the transport cost also enables identification of an upper limit on the final price, since if the latter rises above the import point, it will be purchased abroad, where it is cheaper, instead of at home (Haberler, 1950, p.32). See below: «3. Internationally traded goods according to Haberler».

11 Or in any case very low, depending on the efficiency of the banking system in a given area for operations relating to the inter-bank clearing systems. This consideration applies to a monetary system based on a commodity money where the monetary exchanges are actually executed using money certificates and/or clearing mechanisms (either merchant or bank clearing). Evidently, if we consider the imaginary construction of an economy in which only a commodity money is considered legal tender and is physically exchanged, then the transport cost would not be zero, rather it would correspond to the transport cost of the commodity money.

12 Mises (1953), p. 173.
} 


\section{The general price level and national price indexes}

The idea of measuring the purchasing power of money arises from the plan of controlling and eventually stabilizing its value, which today is considered the main target of the monetary policy. Mises criticized the feasibility of such measurement on the basis of two considerations ${ }^{13}$. Firstly, the concept of the price level is misleading because it does not belong to the real economic activity. Secondly, the usage of index number techniques for measuring such a price level is unscientific, and therefore should not be used in the construction of an economic theory.

The concept of the price level is an imaginary construction that assumes completely stationary exchange ratios between commodities other than money. With relative prices frozen, it is easy to imagine a uniform rise or fall of the price of all commodities; that is, of the purchasing power of money. Furthermore, this abstraction enables us to distinguish whether changes in exchange relationships between money and other commodities arise from the 'money side' or the 'commodity side $^{\prime 14}$. Nevertheless, it is plain to see that this fictional representation does not coincide with the circumstances of the real market process.

The idea of measuring purchasing power by observing the price evolution of an arbitrarily selected basket of commodities, stems (as far as the theory of index numbers goes) from the consideration that the value of money can be seen as the commodity-price of money. Relative price changes - that is, commodity-side price changes - cancel each other out in a sufficiently large and carefully selected collection of consumer

\footnotetext{
13 Mises (1953), p. 187, and Mises (2002a), p. 87.

14 Also called by Mises 'cash-induced' and 'good-induced' changes in the value of money.
} 
goods ${ }^{15}$. Thus, the resulting price movements of this collection represent money-side changes, or in other words, purchasing power changes. However, several arbitrary decisions must be taken in order to build up an index number:

a) The index must be assembled using an arithmetical mean. The debate over which mean should be arbitrarily selected is an old one; for our purpose it is sufficient to underline that the debate cannot be settled conclusively.

b) We cannot consider assigning the same relative importance to every good in the basket. Hence it would make sense to adopt a 'weighted average'. Plainly, however, the subjective value scale of the individual is constantly changing and, consequently, so does the relative importance that he assigns to every good. Therefore, if we want to avoid the ingenuity of believing that the condition of isolated individuals' value scales applies to reality, we must conclude that the array of weight coefficients required to build the 'weighted average' is both unobservable and dynamically changing. Its computation necessarily requires arbitrary assumptions.

In some fields, according to Mises, the approximate calculation of price indexes is acceptable. For example, in the investigation of historical economic events, or when a financial institution needs to estimate the purchasing power component of the market's interest rate. For short time periods the results obtained may be regarded as satisfactory, as long as we remember that they do not represent an exact picture of reality, because of the germ of the arbitrary assumptions they contain.

15 It would be trivial to comment further on the absolute arbitrarity of this assumption. 


\section{The Quantity Theory of Money}

To explain the effects of a change in the money supply, the Austrian theory generally resorts to the Quantity Theory of Money ${ }^{16}$. Haberler reminds us that this theory can be distinguished in two varieties:

- Strict version: prices rise uniformly and in the same proportion as the increase in the quantity of money.

- Relaxed version: an increase in the quantity of money 'tends' to bring about a price rise.

The first version coincides with John Locke's view and was used by Irvin Fisher to build his famous exchange equation. It is well known that the latter is rejected by the Austrians, who call it the "mechanicistic version of the Quantity Theory» ${ }^{17}$. The second version was the essence of the monetary theory of the Classical School and of the Currency School. Its basic principle was established by Richard Cantillon, who explained what exactly happens to prices if it is false that they rise uniformly and proportionally to the volume of monetary expansion. The new money is not distributed homogeneously out of a helicopter directly to the wallets of every economic agent. Instead, it enters into some specific interstices of the economy. In the first instance it will be at the disposal of a few people, whose demand for goods will consequently increase. Hence, the new money will spread initially around the circle of the first agents that receive and spend it, causing a rise in the price of the goods they purchase. The

16 A small branch of Austrian economists do not accept the 'quantity theory'. In substitution they propose a 'quality theory', although this has not yet been developed in a systematic and organic way. The fundaments of the Austrian-rooted prejudices against the Quantity Theory can be found in Anderson, The Value of Money, Chapter VIII, «The Equation of exchange».

17 A brilliant critical review of Fisher's equation can be found in Huerta de Soto (1998), p. 412. See also Anderson, ibid. 
vendors of these goods will then turn their new cash balance excesses to the purchase of other goods, whose price, again, will rise. Thus, the process develops, like a radial wave flowing towards the periphery, until the new money spreads through the economy in accordance with individuals' demand for money and goods. The most significant point here is that during this process, relative prices will change; hence, there is no reason to conclude that the general price level will increase uniformly and in proportion to the increase in the total money supply ${ }^{18}$. Furthermore, at the end of the adjustment process, a redistribution of income will have occurred within the society.

\section{PURCHASING POWER PARITY}

In our times, the Purchasing Power Parity Theory (PPP) represents the building block for all economic theories that deal with the determination of the exchange rate. The 'nominal' exchange rate is defined as the ratio between the number of units of one currency required to buy one unit of another currency. On the other hand, the 'real' exchange rate, one of the instruments mainly used in today's monetary policies, is determined using the purchasing power theory. In this paragraph, we will briefly analyze this in order to underline the differences on this subject between the Neoclassical School and the Austrian School.

The models developed by mainstream Economics also employ another type of parity: the Interest Rate Parity ${ }^{19}$. Those economists who develop their theories using solely the empirical Polar Star,

18 This mechanism is known as the "Cantillon effect», and is so called by the Austrians, particularly by Hayek. Mises (even though he never mentioned Cantillon) used this principle to show that money is never neutral (neither in the short nor in the long term). On this matter, see Huerta de Soto (1998), p. 421 and p. 452. The fluctuations in relative prices induced by the introduction of the Euro represent an evident empirical application of the Austrian principle of non-neutrality of money.

19 See for example Alonso Neira (2004), p. 80. 
observed that the PPP does not successfully pass the empirical test ${ }^{20}$. They then concluded that the theory is acceptable in the long run, but proves inadequate in the short term. The recent development of the international financial markets suggested to them that the exchange rate is influenced not only by relative purchasing powers (as the PPP holds), but also by relative interest rates. Hence, a new set of parity conditions was developed around the idea that the rate of exchange can also be determined by the relation between nominal sovereign interest rates. Again, these parity conditions did not pass the test of the empirical verification and revealed themselves to be more or less consistent with the economic statistics only in the long run ${ }^{21}$.

Today, when a new currency is introduced, the PPP is one of the prime criteria employed in order to establish its equilibrium value. Within the present work, we will see that the Austrians base their analysis on their version of the PPP but decline to rely on the Interest Rate Parity.

\section{Cassel's Purchasing Power Parity Theory}

The Purchasing Power Parity Theory is ascribed by mainstream textbooks to Gustav Cassel. Many Austrians maintain that the first formulation was conceived by Mises ${ }^{22}$. However, already Haberler realized that, even though Cassel introduced the term, the theory is older even than Ricardo ${ }^{23}$. In reality, the first clear formulation of the theory can be traced back to the Spanish late scholastics of the 16th century. In his De Justitia et jure (1553), the famous Salamanca Dominican theologian, Domingo de Soto, applied a rigorous supply-and-demand analysis to foreign

20 See Colombo, Lossani (2003), pp. 147-177.

21 Ibidem.

22 Salerno (1984, p. 253) explains that Mises stated the principle in 1912 (Mises, 1950), four years before Cassel published the first of his many statements.

${ }^{23}$ In the works of John Wheatley (1802) and William Blake (1810). See Haberler, 1950, p. 32, n. 5 . 
exchange rates to explain why the abundance of metal caused a deficit in the balance of payment ${ }^{24}$. Martin de Azpilcueta (known as the 'doctor Navarro'), influenced by Domingo de Soto, developed his theory of exchange rates based on the purchasing power of the monetary unit, and simultaneously discovered the Quantity Theory of Money (Manual de confesores y penitentes, $1553)^{25}$. It is worth noting that another great scholastic, Juan de Mariana, gave the first formulation of The Gresham Law (Tratado sobre la moneda de vellón, 1609) ${ }^{26}$.

The theory asserts that the relative value of different currencies (that is, the exchange rate) corresponds to the relation between the real purchasing power of each currency. Cassel's formulation is more akin with those who maintain that the purchasing power of money can be measured using price level indexes; therefore the ratio between two currencies is equal to the ratio of the general price level in the two countries. This interpretation of the PPP relies on the Law of One Price for all economic goods ${ }^{27}$, a posture that, as mentioned earlier, is strongly opposed by the Austrian School. The fact that the Austrian theory declines to follow the path of price indexes in order to build up economic laws, suggests why Mises' version of the PPP is different.

\section{Mises' Purchasing Power Parity Theory}

Mises clarified the nature of an economy where two kinds of money coexist ${ }^{28}$. For the determination of their exchange rate, there is no theoretical difference between the case of two different kinds of money commonly used side by side within the same economic area (a parallel standard) and the case in which the

\footnotetext{
24 Rothbard (1999), p. 134.

25 Rothbard (1999), p. 136

26 Chafuen (1999), p. 75.

27 Colombo, Lossani (2003), p. 115

28 Mises (1953), p. 179.
} 
money of exclusive use at home is different from that used abroad. This is because, as a result of the existence of international trade relations, the money of each of the single areas concerned is money also for all other areas connected by trade ${ }^{29}$. More specifically, «exchange rates must eventually be established at a height at which it makes no difference whether one uses a piece of money directly to buy a commodity, or whether one first exchanges this money for units of a foreign currency and then spends that foreign currency for the desired commodity» ${ }^{30}$.

Mises' version of the theory is exclusively monetary. It asserts that the static (or long-run equilibrium) exchange rate is always exactly equal to the inverse of the ratio between the purchasing powers of the two currencies. To maintain purchasing power parity it is not necessary for physically identical goods available at different locations to maintain equal prices in the same currency; however, the ratio of the prices of the same good in two different currencies should equal their exchange rate ${ }^{31}$. Obviously, this parity will be safeguarded by the arbitrage mechanism.

The purely monetary nature of Mises' theory of exchange rate determination implies that real factors (including relative price movements between imports and exports) do not intervene in its formation. If the relative price of a commodity rises, it will do so against every currency; in other words, every currency will depreciate in terms of that specific commodity price. Hence, even though relative price movements will bring about a redistribution of income (which eventually leads to a change in the demand for money), they will not be a general cause of departure from the equilibrium exchange rate ${ }^{32}$.

29 However, it is true that there are important differences between domestic and foreign money, as regards the social consequences of a change in the objective exchange value of money. See Mises (1953), p. 206.

30 Mises (1953), p. 250.

31 Salerno (1984), p. 254

32 Salerno (1984), pp. 255-6. 


\section{Internationally traded goods according to Haberler}

Interspatial price differences for the same physical good tend to be leveled, since they represent arbitrage opportunities. However, this does not mean that the price of every single commodity must be the same in all places. We have already mentioned the transport cost factor and the difference in geographical subjective valuations as the two elements that justify interspatial price discrepancies. Now, in Haberler's view, we can take a step further in order to determine the constraints on the pricing process associated with an internationally traded good.

Every commodity has an export and an import point and the distance between the two is the transport $\operatorname{cost}^{33}$. If the price rises above the import point, imports will increase; if it falls below the export point, the commodity will be exported. Within these two limits, the price can vary. Whenever transport is impossible (for example, real estate) or disproportionately expensive, a good ceases to be considered an 'international' good. Moreover, the nearer the cost of production is to the export or the import point, the more likely it is that a good will have the potential to become, or will cease to be, an international good, as a result of small changes in the cost of production ${ }^{34}$ or in the cost of transport ${ }^{35}$.

Before we go further, we should point out two problems in the reasoning presented so far. Firstly, Haberler clearly demonstrates here his marriage to the Marshallian theory of price determination (the predominant one in the neoclassical arena), which is in conflict with the Austrian theory. For both schools, prices are determined by the supply-demand relation; but while

\footnotetext{
33 Haberler (1950), p. 32.

${ }^{34}$ Either for a 'monetary' reason (such as movements in the general price level) or for a 'real' reason (such as a change in technology).

35 For example, owing to the introduction or the elimination of tariffs.
} 
both agree that demand is determined by individual preferences, Marshall maintained that supply is determined by the cost of production, while the Austrians argue that it is the other way around - that is, that the cost of production is determined by the final price ${ }^{36}$. Secondly, Haberler bases his analysis on the fact that only the transport cost justifies interspatial price discrepancies, while we have seen that for the Austrians these price gaps are due also to a subjective component.

The mechanism proposed by Haberler enables us to identify a relation between the price of international goods at home and abroad. The price in the exporting country coincides with or is lower than the export point and in the importing country it will be equal to or greater than the import point. Hence, as the theory goes, there is a price difference for the same good in two different countries, which is justified by the gap represented by the transport cost. Moreover, if the goods are to continue to be traded internationally, both prices must move together.

Moving from the micro to the macro level, the step is apparently short. The transport cost would justify a gap in the aggregate price level between different countries. Hence, the exchange rate determination using this version of the PPP rests on the price level ratio between two countries, with the price levels intended as the aggregate price index of internationally tradable goods ${ }^{37}$.

${ }^{36}$ Austrian theory is strictly consumer-centric. In the long run, production costs (factor prices) are determined by consumption prices, which follow consumers' valuations. See Murray Rothbard, Man, Economy and State 1963a, Ch. 5, par. 8. Mises affirms that «retail prices of consumption goods always participate in the movements of the prices of production goods, even if they lag behind them» and, adding a methodological flavor to the issue, that «it is impossible to prove the cost-ofproduction theory of the older School by invoking the innumerable assertions of business-men that 'explain' variations in prices by variations in costs of production" (Mises, 1953, p. 156 and p. 169).

37 Furthermore, Haberler affirms that «one should not say that the rise in prices is the primary phenomenon, and that the depreciation of the exchange is merely an effect of this. The two changes bear a functional relation to one another and are 
However, here Haberler encounters a difficulty: the theory stands firm as long as all goods (that participate in the aggregate of the price level) are internationally traded. However, noninternational domestic goods also exist, whose price level may not move accordingly with the international price level. He resolves to sidestep this bottleneck by asserting that, indeed, a reasonably close connection exists between the two. Domestic prices would move in the same direction as international prices (even though the proportion of international to domestic goods is small) because the latter «include most of the important raw materials, which influence considerably the price of their products» ${ }^{38}$.

From our point of view, the assumption he makes is a very specific one that does not have a place in any manner of general economic theory. For, in circumstances where the raw materials assumption does not hold, the theory would not be applicable. If we decline to acknowledge any relation of such kind between the price level of international versus domestic non-international goods, Haberler's version of PPP would hold in the narrower (if not inconceivable) realm of price levels for international goods. Considering that national price indexes include purely domestic goods, their applicability (even for those who accept their usage in the construction of economic laws) proves very limited.

Nonetheless, there is one final argument that challenges Haberler's position. According to Mises, there is no reason to distinguish between internationally tradable goods and domestically produced and consumed 'non-tradable' goods. All goods that are exchanged in the market participate in the formation of the purchasing power of the national currency, since

both effects of the same cause», that is, the increase in the quantity of money (Haberler, 1950, p. 60).

38 Haberler (1950), p. 35. Here, again, we have a confirmation that he follows Marshall in price determination. 
all goods are potential objects of trade even though many may be 'immovable'. For example, American real estates, when rendered sufficiently cheap by dollar depreciation, are the object of foreign speculation ${ }^{39}$.

\section{BALANCE OF PAYMENTS ADJUSTMENTS}

\section{The case of an homogeneous international money}

a) The basic mechanism

Hayek describes the function and the mechanism of international movements of money examining the case of a shift in the demand for consumer goods ${ }^{40}$. He considers the simple case of an international homogeneous money (or purely metallic money) and supposes that an individual that previously consumed a product of country A decides to switch to the consumption of a different good of country B. The outcome will be the following:

- The decreased exports in A and the increased exports in B generate a flow of payments from A to B; that is, an adverse balance of trade for country A.

- Someone will have to account a monetary income decrease in country A and the opposite will happen in B.

- The income change will spread through the two economies, setting in motion forces aimed in opposite directions, which will compensate the equilibrium in the balance of payments and will stop the flow of payments. In country A the income decline will lead either to a reduction of imports from country $B$ or to a fall in the price of some goods, which will facilitate

39 Salerno (1984), pp. 253-4.

40 Hayek (1937), 2nd Conference (p. 102, sp. Ed.). The mechanisms described here are rooted in the Quantity Theory of Money and can also be found in Mises (1953), p. 249 and Mises (2002a), p. 33. 
an increase of exports toward B. The opposite forces appear in country B.

- At the end of the counteracting process, the money flux from A to B will stop and the total of the transferred funds will coincide with the reduction of the quantity of money in A and the increase of this in $B$.

- The process will terminate not when the balance of payments between the two countries meets a new equilibrium, but when the individuals affected by the process do so also. This means that even if the money flux between the countries ends, the effects of the adjustment process may not have been terminated at the individual level. Furthermore, the magnitude of the reduction in income and individual prices (and not its aggregate level) that may arise as a consequence of the money transfer from $A$ to $B$ may prove to be greater in $\mathrm{B}$ than in $\mathrm{A}$.

Using this simple scenario, Hayek shows that what drives the chain of effects unleashed by the originating cause of the monetary disequilibrium are the individual's decisions (in terms of cash balances, income and prices), and not the movements in national money supply, nominal GDP or price level. Moreover, these movements in the individual's income and prices will not differ from those that occur in the case of two domestic industries or of two regions of the same country.

Far more important are the implications of the adjustment of this balance of payments in terms of changes in the money supply. In the case of interregional or international money transfers such as the one described above, it does not make much sense to speak of inflation or deflation. Clearly, if we define these two phenomena as either the change in the money supply or the price level within an arbitrarily selected territory (that is, a portion of the international setting under consideration), then the employment of these two terms makes sense. But here 
we are dealing with an international redistribution of money, rather than a simple change in the money supply of two closed economies. More specifically, there are no reasons to consider that:

a) The monetary expansion/contraction within a given geographical area will generate those relative price movements that bring about malinvestment and set a business cycle in motion ${ }^{41}$.

b) Savings and investments will be equal within, again, an arbitrarily selected territory that represents a portion of the international economy under investigation.

b) The balance of payments and the demand for money

Mises analyzes the implication of the demand for money ${ }^{42}$ for the balance of payments, under the assumptions of an unhampered market, free trade and absence of fiduciary media. We have already seen that «all economic goods, including money, tend to be distributed in such a way that a position of equilibrium between individuals is reached». In such a position, the total money supply (as with the total stock of other commodities) is distributed among individuals according to the intensity of their demand for it in the market. Moving from the micro to the macro level, the same applies without amendments ${ }^{43}$. "If the state of the balance of payments is such that movements in money would have to occur between countries, independently of any altered estimation of money on the part of their respective inhabitants, then operations would be induced which reestablish equilibrium. Those persons who receive more money than they

41 Note that the change comes from a consumer choice (perhaps justified by the competitiveness of the product of country A against the product of country B), and not from the availability of cheap money, which generates malinvestment.

42 See Appendix A.

43 Mises (1953), p. 184. 
need will hasten to spend the surplus again as soon as possible, whether they buy production goods or consumption goods. On the other hand, those persons whose stock of money falls below the amount they need will be obliged to increase their stock of money, either by restricting purchases or by disposing of commodities in their possession» ${ }^{44}$. In other words, as long as the demand for money does not change, a credit or debit balance of payment can only be transitory. Thus, the cause of a permanent departure from the equilibrium toward which the market is moving must be found not in a temporary unbalance of international movements of money, but rather in a change in the demand for money.

\section{The case of a national money: fractional reserve banking}

Hayek extends the previous case to consider the existence in both countries of a fractional reserve system. The clients of a bank in country A are used to considering as money their deposits at, or the notes issued by, an institution that participates in the national banking system. But when international trade is involved, the transaction must be settled using international (or metallic) money. Therefore, in order to make an international payment, the individual has to exchange the domestic money for international money (that is, to redeem the fiduciary media in his possession).

In a fractional reserve system ${ }^{45}$, the banks hold in reserves a small portion of the amount of money they issue in the form of deposits or notes. These reserves enable redemption requests, which the banks receive as a result of the balance arising from

\footnotetext{
${ }^{44}$ Ibid.

45 Huerta de Soto (1998) is considered the most advanced and innovative Austrian monograph on this subject.
} 
intra-banking clearing and foreign operations, to be met. The financial institutions participating in the national banking system usually keep their reserves in the deposit of a central bank, which is therefore in a position to supervise and, if need be, control the aggregate reserves of the participating national banks ${ }^{46}$. The proportion of reserves to the volume of fiduciary media issued is a critical one, and the credit structure of the country is affected by the volume of reserves. Indeed, if the latter changes, the national credit system will expand or contract accordingly.

We are now in a position to return to the previous case (a consumer demand shift that generates an international movement of money), enriched by the presence in each country of a distinct fractional reserve system superintended by a central bank ${ }^{47}$. The general opinion is that the effects produced will be identical. However, for Hayek, such a conclusion bears the view of the mechanicistic interpretation of the Quantity Theory of Money, which oversimplifies the mechanism and therefore neglects several significant repercussions.

We have seen that a shift in demand for goods involved in international exchange will render the balance of payments for country A unfavorable, owing to a transfer of money toward country B. However, in this case, unless the adjustment process is particularly rapid, the central bank will not allow it to evolve spontaneously until a new equilibrium is reached, since this could jeopardize the reserves accumulated for the redemption

46 Mises examines the workings of this collective reserve fund (that he calls 'redemption fund'). The estimation of this enables us to calculate the maximum limit of fiduciary media issues in order to conduct foreign trade securely without the need for a redemption fund. However, if those who trade with foreigners find it costly to convert money-substitutes (such a circumstance would militate against the complete equivalence of money-substitutes and money), these would circulate at a discount. In this case, a redemption fund would be necessary. Mises (1953), p. 325-331.

47 Hayek (1937), $2^{\text {nd }}$ Conference (p. 107, sp. Ed.). 
of fiduciary media. This is so because if the level of reserves falls, the risk of insolvency rises; therefore, in order to maintain the proportion of liquidity to fiduciary media issued (whether in the form of deposits or notes), a contraction of the national credit structure will be pursued. Likewise, this creates the conditions for a credit expansion in country B.

In both cases, the result of the adjustment process will be the movement of a quantity of money from one country to the other. The main difference is the set of economic agents that must bear the burden of the correction. In the previous case, only those engaged in the international trade affected by the shift in demand were implicated in the adjustment process. Now, conversely, the credit restriction indiscriminately affects anyone who depends on bank credit; that is, those who rely on bank credit for investments in their business activity.

The fractional reserve system bears the following further implications:

- The forces that contribute towards reestablishing the equilibrium (in other words, which will reduce imports and increase exports) will act in the form of a reduction in domestic prices in country A.

- Intervention in the adjustment mechanism will shorten the time scale of the process and will decrease the final quantity of money transferred ${ }^{48}$.

- In the previous case there were no reasons for a rise in the interest rates in country A. In a fractional reserve system the interest rate rise will be inevitable, regardless of the underlying real conditions such as the return on investments or the social saving rate. This means that, the interest rate will rise

48 This is so because the monetary outflow required in order to reestablish the balance of payment equilibrium is suffocated by the national credit expansion/contraction. So the process will not develop completely, as in the previous case, but only partially. 
above its natural or equilibrium rate ${ }^{49}$. It should be underlined that this movement of interest rates: (a) is not caused by the original shift in demand, but by the type of banking structure, which is forced to react in this way when such alterations occur; (b) represents the very measure that allows for acceleration of the process that reverses the unfavorable balance of payments.

- The attained equilibrium of the payments balance will be transitory since, as mentioned above, those people forced to contract their purchases are not the same people that would be affected in the absence of a fractional reserve system. In other words, such equilibrium has been reached through a monetary-induced alteration of the investment structure and not by changes in underlying real factors.

- It could be asserted that the credit contraction in country A and the expansion in B produces exactly the same effects as a transfer of capital from $\mathrm{A}$ to $\mathrm{B}^{50}$, therefore no damage is produced in the credit structure. However, not every money transfer is equal to a transfer of capital, since there is no guarantee that those who receive the monetary transfer will increase their investments. The matter would be different if the original cause were not a shift in the demand for commodities from those produced by country A to those produced by B; but rather, if it were a redirection of the funds invested in the production of capital goods in country A to those produced in country B. This would represent an authentic capital movement and would have a 'direct' effect on the interest rates.

\footnotetext{
${ }^{49}$ Generalizing, assuming an initial disequilibrium condition, the interest rate will tend to increase.

50 See section on Hayek in «b) Hayek: international capital movements and interest rates» for a definition of capital movements.
} 
It is useful to reiterate that the problems underlined here are not caused by the political measures or regulations determined by the central bank, but rather by the very essence of a collective system of fractional reserves.

On this subject, Haberler does not recognize the problems identified by Hayek ${ }^{51}$. He explains that credit expansion/contraction modifies the quantity of money in circulation, without changes in the amount of legal tender. This leads to movements in 'nominal purchasing power' without the transfer of gold. Hence, gold movements no longer play a prominent part, although their mechanism does not cease to operate. Consider a world-wide clearing system and the existence of an international central bank. National central banks' gold reserves are deposited at the international bank, or are superseded by credit held there by central banks. A passive balance of trades would mean a movement of gold from one account to the other, without the material transfer of gold. In any case, the mechanism of pricelevel, balance of trade, etc., would remain fully operative. This is what actually happens, with central banks keeping money at foreign banks. A passive balance of payments leads to shrinkage of these accounts, causing banks to restrict credit. With small disturbances, equilibrium is restored in this way, with neither gold movements nor a fall in the exchange rate.

\section{The case of inconvertible paper currencies}

Inconvertible paper currencies are not pegged to the value of an internationally acknowledged money such as, for example, in the gold standard ${ }^{52}$. Rather, their relative value fluctuates in the open market, as the price of ordinary commodities does, responding to the law of Purchasing Power Parity. Besides, a

\footnotetext{
51 Haberler (1950), pp. 51-52.

52 For a brief description of the mechanism of the gold standard and of the gold points, see Haberler (1950), p. 23.
} 
passive balance of payments does not result in an outflow of money, but rather in a currency depreciation.

a) The flaws of the balance of payments theory

In his monetary writings, on more than one occasion Mises faces the issue of the balance of payments theory. This theory seeks to explain the formation of exchange rates based on the current state of the balance of payments, rather than via the currency's purchasing power ${ }^{53}$. If the balance of payments debit increases (either through an increase in payments due to foreigners or owing to a decrease in incoming payments), the foreign exchange must rise.

The theory traces a distinction between the decline in the currency's value on the international markets and the reduction of its domestic purchasing power. In fact, according to this theory, there is a weak connection between the two, if any connection at all. Mises explains that between the change in foreign exchange and the change in the monetary unit's domestic purchasing power, there is usually a time lag (shorter or longer); therefore a superficial observation could easily lead to the conclusion that the two data are independent of one another. The time lag is due to the fact that price increases (induced by a rise in the quantity of money) do not appear overnight. They evolve according to the mechanisms of the Cantillon effect. On the other hand, foreign exchange quotations are speculative rates of exchange, therefore the depreciation of the currency becomes apparent relatively soon in the foreign exchange market, long before the prices of other goods and services are affected. Hence, the theory easily overlooks the fact that «(a) the day-today ratio between supply and demand for foreign exchange determined by the balance of payments can evoke only transitory

53 Mises (2002a), p. 57. 
variations from the static rate determined by the purchasing power of the various currencies, (b) these variations must disappear promptly, and (c) these variations will vanish more quickly and more completely the less restraints are imposed on trade and the freer speculation is» 54 .

According to the doctrine of the balance of payments, the maintenance of a sound currency is possible only with a 'credit' balance of payments. The instruments for the refutation of this thesis are the Quantity Theory and Gresham's Law ${ }^{55}$. The former tells us that money cannot fly out continuously from a country that employs a purely metallic currency. «The outflow of a part of the gold supply brings about a contraction in the quantity of money available in the domestic market. This reduces commodity prices, promotes exports and restricts imports, until the quantity of money in the domestic economy is replenished from abroad $» 56$. An undesired efflux of money can never be anything but the result of Government intervention endowing money of different values with the same legal tender. The mechanisms of Gresham's Law come into action when a country substitutes metallic money with credit money or fiat money, since the economic agents are forced to recognize legally the over-issued paper money as equal to metallic money ${ }^{57}$. In this case, it is often asserted that

54 Mises (2002a), p. 58.

55 Mises (2002a), p. 33 and Mises (1953), p. 249. This law states: «Money overvalued artificially by government will drive out of circulation artificially undervalued money». See Murray N. Rothbard, What Has Government Done to Our Money? (1963b), p. 17. The law is often superficially enounced as: «Bad money drives good money out of circulation».

56 Idem.

57 Money does not flow out because the balance of payments is unfavorable, but rather because state intervention has called forth the mechanism of Gresham's Law. The disappearance of gold money follows from the fact that the state equates, in terms of legal tender, a lesser-valued money with a higher valued money. Introducing quantities of inconvertible banknotes and government notes it forces monetary depreciation on these notes, while gold money retains its international value and vanishes, henceforth, from the market (disappearing abroad or going into hoarding). Mises (2002a), pp. 61-62. 
the balance of payments determines the exchange rate. To Mises, this is completely wrong. We have already seen that the static exchange rate is determined by the purchasing power parity and that short-term deviations are due to healthy speculative movements that actually drive the forward change toward this rate $^{58}$. Furthermore, one must not overlook the fact that foreign trade exists because of interspatial price discrepancies. If, when observing daily fluctuations, we realize that the "momentary state of the balance of payments is decisive for supply and demand on the foreign exchange market», we should take a step further and conjecture as to what determines the state of the balance of payments. "This must lead to the conclusion that the balance of payments is determined by the structure of prices and by the sales and purchases inspired by differences in prices» ${ }^{59}$.

Another interesting contribution by Mises underlines that if between two countries international trade is carried out by barter, then the balance between the two countries must be even ${ }^{60}$. This does not change from direct to indirect exchange: the surplus of the balance of payments that is not settled by the consignment of goods and services but rather via money transfer was, for a long time, believed to be a consequence of international trade. This is erroneous. International money movements are not the effect, but the cause of a favorable or unfavorable balance of trade ${ }^{61}$. Precious metals are distributed among individuals (hence among nations) according to their demand for money.

58 Mises (2002a), p. 35.

59 Idem.

60 Mises (1953), pp. 180-187.

61 The balance of payments of a country is nothing but the sum of the balance of payments of all its individual enterprises. Debit and credit sides must always be in balance, because in economic trading goods are exchanged, not given away. This equilibrium is not brought about by undertaking all export and imports first, without considering the means of payment, and only later adjusting the balance in money. Rather, money occupies the same position in undertaking transitions as do the other commodities being exchanged. Mises (2002a), p. 60. 
Therefore, no individual must fear having less money than he or she needs ${ }^{62}$.

\section{b) Hayek: international capital movements and interest rates}

Hayek defines international capital movements as «the purchase or sale of rights, credits against the residents of a country to the ones of another, [or] properties located in a country owned by people resident in another country» ${ }^{63}$. The reason for this definition is that it is the only one that enables capital movements to be distinguished from non-capital movements.

The purchases and sales of foreign currency between citizens of different countries must be considered capital movements. They are settled in the form of movements in bank accounts in one country in favor of banks or individuals in another country. This is so since it is much more economical to credit or debit the difference generated by these operations through a bank account instead of sending physical money. These balances are often maintained in the form of interest-bearing deposits.

We are now in a position to examine the characteristics of international capital movements in the following three cases: (i) fixed exchange rates; (ii) fixed exchange rates within the context of a fractional reserve system; (iii) flexible exchange rates.

62 In a society where commodity transactions are monetary transactions, every enterprise or individual carries a cash holding for carrying out its transactions in order to pursue its own interest. Hence, it is impossible for the free play of the market forces to cause all money to be drained out of a city, a region or a country. In a pure gold standard, the government need not be concerned about the balance of payments; it could safely leave the responsibility of maintaining a sufficient quantity of gold within the country to the market. Mises (2002a), p. 60.

63 The definition excludes: the exchange of commodities that are delivered at the time they are paid for and any net movement of gold or other international money (including unilateral money transfers), as long as they imply the transmission of the property of money without creating rights for the residents of one country against those of the other. Hayek (1937), 2nd Conference (p. 125, sp. ed.). This conference is the basis of this paragraph (idem, pp. 125-137). 
(i) In the context of fixed exchange rates against an homogeneous international money, such as in the case of a pure gold standard, capital movements would follow the expected return on investments, which includes the risk premium. Apart from these investments, there could be short-term loans that would occasionally cover temporal differences between imports and exports. Clearly, if all transactions were to be liquidated in cash, this would mean a considerable restriction for trade: the possibility of effecting credit transactions widens the volume of trade. Regardless of the nature of these transactions (commercial credit between merchants or bank credit), they represent an import of shortterm capital. From Hayek, we should reject the idea that short-term loans are caused by a debit balance of trade. It would be more correct to affirm that an excess of loans in one direction allows for an excess of exports in that same direction. Furthermore, it would be wrong to think that these movements are determined by relative interest rates in the money markets ${ }^{64}$. For what drives available credit is the existence of price discrepancies. Clearly, if exports are financed, when their demand increases the demand for loans rises too, and so do the interest rates. However, this interest rate increase is not due to an increase in capital imports, but to an increase in loans to foreigners. Only the balances remaining at the end of the credit process are

64 Mises affirms that money does not flow to the place where the rate of interest is highest, neither is it true that rich nations attract money. Just like every other economic good, money distribution depends on its marginal utility. To grasp this conclusion, we can suppose the imaginary construction of an unregulated market, with freedom of trade and absence of fiduciary media. In this case, all economic goods, including money, tend to be distributed in such a way that an equilibrium position is reached among individuals. Money, finally, is distributed according to the demand expressed by individuals throughout their participation in the market. The same happens moving from the micro to the macro point of view, as the sum of individuals' contributions is considered. See Mises (1953), pp. 180-187. 
liquidated by net money transfers, which, being of an interbanking nature, are determined by relative interest rates.

(ii) If a fixed exchange rate system is considered jointly with the workings of fractional reserve banking, we must add the presence of national monetary authorities (central banks), which act upon the discount rate in order to affect short term capital movements, with the objective of safeguarding the domestic redemption fund. In this case, international capital movements become more drastic and frequent. Again, it should be underlined that the problem is not caused by the presence of the central bank, but rather by the existence of currencies with different degrees of liquidity and acceptance. More specifically, the existence of layers of reserves of varying degrees of liquidity makes it possible for the changes in the monetary interest rates and the short term movements of the produced funds to depend more on the liquidity position of the distinct financial institutions than on the real demand for capital investments. Hence, short-term movements of funds are often due to changes in the demand for cash reserves rather than to modifications in the demand for investments.

(iii) Under a flexible exchange rate regime, bank accounts dedicated to the settlement of balances arising from the purchase and sale of foreign currency assume a higher importance. Even if bank accounts in foreign currency represent only one part of the volume of short-term foreign investment, they represent the major one ${ }^{65}$. Any change in international indebtedness manifests itself in this manner. It should be pointed out that it is particularly difficult to define exactly what should be classed as short-term capital movement. If we put aside long-term loans, almost all forms

65 Indeed, compared to the large funds held in these foreign currency bank accounts, long-term investments play a very small role (Hayek, 1937, p. 127, sp. Ed.). 
of international investments must be considered short-term investments, including all investments in securities.

Furthermore, if a bank contracts obligations in different currencies, it will be necessary to hold a reserve for each one of them. Since gains or losses in these currency balances arise when the exchange rate fluctuates, the anticipation of these variations will be the object of speculative operations ${ }^{66}$. Hence, expectations over exchange rate fluctuations are a powerful source of international capital movements, responding to very different reasons from those that operate in a well-established international monetary standard.

When the exchange rate fluctuates freely within an established band that the monetary authority promises to preserve ${ }^{67}$, capital movements will reduce the amplitude of the fluctuations, since any movement towards one of the two limits will generate the expectation of a reversal. In other words, short-term capital movements tend to moderate the pressures arising from temporary changes in the balance of payments. Conversely, when exchange rates are completely free, speculative movements tend to exacerbate (that is, to amplify) the amplitude of fluctuations.

A different matter is whether the monetary authority is able to control such movements. The idea in support of flexible exchange rates is that the central bank is released from the obligation of increasing domestic interest rates in order to counteract an outflow of money that could jeopardize the country's liquidity. A depreciation of the currency substitutes the mechanisms involved in the maintenance of a pegged currency. However, the effort to maintain low interest rates can only result in the indefinite perpetration of the circumstances that originated the initial exhaustion of capital and in a continuous

${ }^{66}$ Clearly, the mere suspicion that a currency will depreciate represents a solid reason for moving the funds denominated in this currency to accounts in a currency that promises stability or an appreciation.

67 Such as in the case of the gold points or of modern target zones. 
and progressive depreciation of the exchange rate. The outflow of capital will tend to cause an increase in the country's natural (or equilibrium) interest rate. Sooner or later, this will force the central bank, if it wants to avoid the eventuality of hyperinflation, finally to increase the interest rate ${ }^{68}$.

\section{c) Mises: international interest rates}

On this subject it is interesting to review briefly Mises analysis ${ }^{69}$. In the credit market of the countries that participate in international trade, the net interest rate is determined by the natural international rate and not by the domestic one. Attempts to reduce the domestic interest rates by influencing the international movements of capital are particularly pronounced in the money market, that is, the market for short term capital investments. If the monetary authority opposes the increase in interest rates (which is believed to be negative for the collective) because of an efflux of gold, itself due to the participation of the country in international trade, its attempt is erroneous. It does not take into account that the movement of gold represents an automatic adjustment in the domestic interest rate against the world interest rate, the country being immersed into an international setting. If banks lower the interest rate below the international natural value, capitalists will have the desire to invest abroad, and this raises the demand for foreign exchange. The fall in the exchange rate will not set in motion forces that reestablish the relation between bank money and gold (that is, the world currency) that previously existed. Such autonomous interest policies will necessarily lead to a progressive depreciation.

${ }^{68}$ In the same conference Hayek exposes a very interesting examination of the employment of capital controls. However, this argument goes beyond the scope of this survey. Hayek, 1937 (p. 135, sp. Ed.).

${ }^{69}$ Mises (1953), pp. 373-377. 
In his analysis, Mises does not differ from Hayek's position in relation to the effects of a low interest discount policy. In the case of the absence of a fractional reserve system, we have seen that the domestic interest rate does not depend on international money movements. The presence of such a banking system promotes the abandon of the natural rate level (which would otherwise develop in harmony with the international rates). That is why Hayek's analysis is focused on the evolution of the domestic natural interest rate, while Mises' analysis concentrates on the international counterpart. However, we have seen that Mises clearly rejects the idea that money flows to the place where the rate of interest is highest, while Hayek leaves a door open, albeit not overtly, for short term movements of capital. In a fixed exchange rates regime (where we can assume that expectations of appreciation/depreciation are nil), we cannot negate that the interest rate born by foreign bank accounts may represent a reason for keeping money in one currency rather than another. With flexible exchange rates, the speculative component must be added to the array of incentives. This subject undoubtedly deserves further investigation, specifically to determine whether or not it makes sense to contemplate the Interest Rate Parity as a tendency law ${ }^{70}$ in the Austrian Theory, and, the case arising, under what circumstances.

d) Haberler: the discount policy

We have briefly analyzed the implications on the exchange rate of the existence of reserve regulations (which lay down a definite relation between paper money and cash reserves), intended as a supposed automatic brake to prevent excessive paper money issue. In addition, the central bank can directly or indirectly

70 That is, not as a mechanical law. 
influence the exchange rate via the discount policy ${ }^{71}$. The changes in the bank rate affect the exchange rate because of two effects:

- Directly: By causing an inflow or outflow of short-term investments. This is the most powerful effect since the central bank supplies an appreciable portion of the money market (it may be regarded as the marginal lender). Moreover, it exercises a strong psychological influence ${ }^{72}$. However, the effect of this nature of measure is transitory.

- Indirectly: A rise in the bank rate leads to a fall in prices, since it causes a reduction of note circulation.

A rise in the interest rate implies a fall in the price of all securities bearing a fixed rate of interest, since other lines of investment at the same financial center become more attractive. However, the consequent fall in prices induces foreigners to buy; therefore the balance of payments is affected in the same way as a fall in commodity prices. This connection (interest rate price of fixed income securities) allows the central bank to enforce the discount policy - that is, to obtain the same kind of effect - through 'open market' operations (buying and selling government securities).

This does not mean that there should be the same interest rate in all countries. Haberler maintains that the tendency towards an equality of interest rates must be understood in the same sense as that of the commodity prices. For, here, the role of the transport cost is played by the risk factor ${ }^{73}$ and it may

71 Haberler (1950), pp. 48-51.

72 From the theoretical point of view, the reader should bear in mind that orthodox central banking takes the credibility factor carefully into account. Furthermore, from the empirical point of view, he/she should contemplate the suspense generated in financial markets every time a central banker, such as Alan Greenspan, makes an official statement.

73 Here we do not agree with Haberler, since the risk factor is present in international commerce also. We previously criticized his rigidity in the contemplation of the transport cost as the only determinant of interlocal price discrepancies. As before, the essence of Haberler's position here could be saved, from the Austrian point of 
require a considerable difference in interest rates to induce concrete capital movements. All that can be asserted is that a rise in interest rates 'tends', ceteris paribus, to attract foreign capital and to dissuade domestic capital to flow out.

\section{CONCLUSIONS}

This survey was conceived with the aim of compiling the most significant contributions of Austrian economists on the subject of the exchange rate determination.

In the first part, we briefly reviewed the Austrian theoretical instruments that enable an analysis of the notion of purchasing power. We analyzed the fundamental differences compared with the mainstream orthodoxy and built up the micro foundation with a view to examining the forces that determine exchange rates.

In the second part, we conducted an assessment of the concept of the Purchasing Power Parity Theory underlining the gap that exists between the version widely accepted by the mainstream, Cassel's alternative, and the formulation provided by Mises back in 1912. Furthermore, we examined Haberler's interpretation of the theory and enumerated its problems and inconsistencies with the Austrian Theory. Finally, we mentioned that the PPP principle can be traced back to the Spanish Scholastics of the 16th century.

In the third part, following Hayek's analysis, we examined the international movements of money and the associations of these with the dynamics of the balance of payments and exchange rate. We followed the Nobel Prize winner in his illustration of three different cases: the case of an international homogeneous money, the case of a fractional banking system, and the case of

view, by introducing a dose of subjectivity into the preferences of the economic agent. 
international money movements under the different exchange rate regimes. We have seen that the Austrians rely on the PPP for the determination of the exchange rate and decline to use interest rate differentials in order to explain international money movements or in the determination of the exchange rate. This characterizes the most important point of this survey. Today's mainstream economics makes extensive use of the notion of Interest Rates Parity. A further step towards the Austrian Theory of exchange rate determination will investigate the feasibility of the introduction of an Austrian formulation of this notion according to the general economic theory rooted in the teachings of the Austrian School.

\section{APPENDIX A: \\ MISES' DEFINITION OF THE DEMAND FOR MONEY}

Laidler's pamphlet The Demand for Money ${ }^{74}$ represents the best survey of neoclassical theory on the subject. Unfortunately, even if the author presents the various schools with an infrequent intellectual honesty, the Austrians are not ascribed in his play script.

Mises builds up the analysis of the demand for money ${ }^{75}$ starting from the individual perspective ${ }^{76}$. The demand for money of a given community is not derived from the quantity of goods that the community has to pay for in a given period, or from the velocity of circulation. For Mises, it is wrong to begin to determine the demand for money on the basis of these aggregate magnitudes, because a community is not an economic

${ }_{74}$ Laidler (1969).

75 That is, the quantity of money that a person believes to be adequate in order to cover his personal and business needs.

76 Mises (1953), p. 133. 
agent; only its individual members demand money to conduct economic exchanges. The demand for money of an economic community is, as trivial as it may seem, the sum of the demand for money of its members. At the individual level it does not make sense to apply the formula «total volume of transactions divided by the velocity of circulation». In order to approach the problem in the correct way, we must take as a starting point the elements that influence individuals' cash balance decisions.

The definition proposed by Mises for the demand for money depends on the monetary environment under consideration:

\section{Absence of fiduciary media}

Personal cash balance may comprise a mix of money and money substitutes $^{77}$. We can therefore distinguish two types of demand for money:

- Demand for money 'in the broader sense' : the entire demand of an individual for money and money substitutes (determined by the will of the individual).

- Demand for money 'in the narrower sense': his demand for money proper (somewhat independent from the individual preference, if we disregard the existence of money substitutes that bear interest, such as bank deposits).

In as far as money substitutes do not exist, social demand (aggregate demand) and the social stock of money are merely the respective sum of the individual demands and stocks. However, when money substitutes are considered, the social demand for money in the narrower sense is no longer the sum of the individual demands for money in the narrower sense; the same applies to the social demand for money in the broader sense.

77 Secure claims to money, payable on demand, generally tendered and accepted in place of money (Mises, 1953, p. 132). 
This is so because part of the money substitutes in circulation are covered by money held in redemption funds at the places where they are cashable.

\section{Presence of fiduciary media}

Money substitutes may be covered entirely or partially by the equivalent sum of money. In the first case we speak of money certificates, while in second we encounter fiduciary media. The former change the definition of the demand for money in the broader sense. For when we calculate the demand for money and money substitutes, to account as money proper the same amount that serves to cover money substitutes at the bank is to double count the same quantity. Hence, definitions change in the following way:

- Demand for money 'in the broader sense': sum of individual demands for money proper plus fiduciary media (including the demand for coverage).

- Demand for money 'in the narrower sense': sum of demands for money proper plus money certificates (excluding demand for coverage).

Finally, Mises summarizes the demand for money for international trade $\mathrm{e}^{78}$. This consists of two components:

- Those balances that arise in the international exchange of goods and services. These must be settled by transfers in opposite directions, therefore it is theoretically possible to have them completely eliminated by the clearing process.

- The sums required as a consequence of a change in the demand for money in different countries.

78 Mises (1953), p. 327. 


\section{BIBLIOGRAPHY}

Alonso NeIRA, M.A. (2004), Teoría económica de las crisis monetarias y financieras y de los controles de capital, Instituto de Estudios Económicos, Madrid.

Anderson, B. (1917), The Value of Money, The Macmillan Company, New York.

ChAfuen, A. (1999), Cristiani per la libertà, Liberilibri (original: Christians for Freedom, 1986).

Colombo, L. (2003), Economia Monetaria Internazionale, Ed. Carrocci, Roma.

Garrison, R.W. (2001), Time and Money, Routledge, New York.

Haberler, G. (1950), The Theory of International Trade, William Hodge \& Company.

HAYEK, F.A. (1937), Monetary Nationalism and International Stability (Spanish translation: El nacionalismo monetario y la estabilidad internacional, in Ensayos de Teoría Monetaria, II, F.A. Hayek, Obras Completas, vol. VI, 2001, Madrid, Unión Editorial).

Huerta de Soto, J. (1998), Dinero, crédito bancario y ciclos económicos, Unión Editorial.

LaIDler, D. (1969), The Demand for Money: Theories and Evidence, International Textbook Company, New York.

Mises, L. von (1953), The Theory of Money and Credit, Yale University Press.

- (1963), Human Action, fourth revised edition, Fox \& Wilkes, San Francisco.

- (2002a), The Manipulation of Money and Credit, The Ludwig von Mises Institute.

- (2002b), The Ultimate Foundation of Economic Science, FEE, New York.

Rothbard, M. (1963a), Man, Economy and State, The Ludwig von Mises Institute.

- (1963b), What Has Government Done to Our Money?, The Ludwig von Mises Institute. 
- (1999), Historia del pensamiento económico, vol. I, Unión Editorial, Madrid (original: An Austrian Perspective on the History of Economic Thought, vol. I, 1995).

- (2000), America's Great Depression, The Ludwig von Mises Institute.

SAlerno, J. (1984), International Monetary Theory, in The Elgar Companion to Austrian Economics, edited by Peter Boettke, Edward Elgar Publishing. 